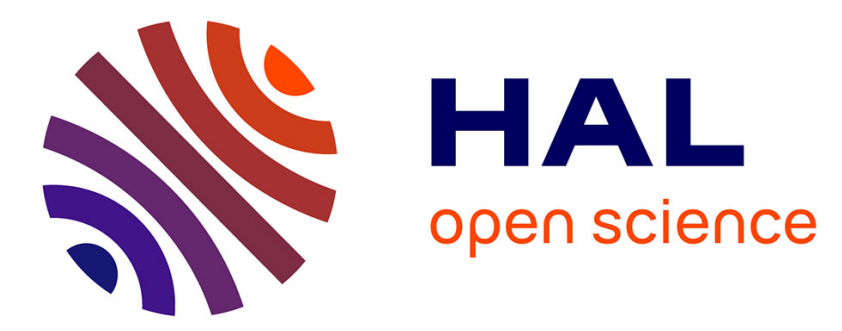

\title{
GATA-4 transcription factor regulates hepatic hepcidin expression.
}

\author{
Marie-Laure Island, Nadia Fatih, Patricia Leroyer, Pierre Brissot, Olivier
}

Loréal

\section{- To cite this version:}

Marie-Laure Island, Nadia Fatih, Patricia Leroyer, Pierre Brissot, Olivier Loréal. GATA-4 transcription factor regulates hepatic hepcidin expression.. Biochemical Journal, 2011, 437 (3), pp.477-482. 10.1042/BJ20110225 . hal-00608393

\section{HAL Id: hal-00608393 https://hal.science/hal-00608393}

Submitted on 13 Jul 2011

HAL is a multi-disciplinary open access archive for the deposit and dissemination of scientific research documents, whether they are published or not. The documents may come from teaching and research institutions in France or abroad, or from public or private research centers.
L'archive ouverte pluridisciplinaire HAL, est destinée au dépôt et à la diffusion de documents scientifiques de niveau recherche, publiés ou non, émanant des établissements d'enseignement et de recherche français ou étrangers, des laboratoires publics ou privés. 
GATA-4 transcription factor regulates hepatic hepcidin expression.

Marie-Laure ISLAND*, Nadia FATIH*, Patricia LEROYER*, Pierre BRISSOT ${ }^{*},+, \neq$ and Olivier LOREAL ${ }^{*},+\ddagger$

*UMR-INSERM U991, IFR140, University of Rennes 1, Rue Henri Le Guilloux 35033 Rennes cedex, ${ }^{\dagger}$ French National Centre for Rare Genetic Iron Overload Diseases, Hopital Pontchaillou 35033 Rennes cedex ${ }^{\ddagger}$ Liver Disease Department, University hospital, 35033 Rennes cedex, France.

Short title: GATA-4 enhanced hepcidin gene expression

Corresponding author: Olivier LOREAL, UMR - INSERM U991, Hospital Pontchaillou,35033 RENNES, FRANCE - E-mail: olivier.loreal@rennes.inserm.fr - Phone: (33) 299543737. Fax: (33) 299540137.

ABBREVIATIONS USED: TfR2, transferrin receptor 2; IL, interleukin; STAT-3, signal transducer and activator of transcription-3; BMP, bone morphogenetic protein; BMP-RE, bone morphogenetic protein-responsive element, MRE, metal response element; MTF-1, MRE-binding transcription factor-1; C/EBP $\alpha$, CCAAT/enhancer-binding protein $\alpha$; CREBH, cyclic AMP response element-binding protein $\mathrm{H}(\mathrm{CREBH})$; EMSA, electrophoretic mobility shift assay 


\begin{abstract}
Hepcidin, an hormone mainly synthesized by hepatocytes and secreted in plasma, controls iron bioavailability. Thus, by inducing the internalization of the iron exporter ferroportin, it regulates iron release from macrophages, enterocytes and hepatocytes towards plasma. Abnormal levels of hepcidin expression alter plasma iron parameters and lead to iron metabolism disorders. To understand the mechanisms controlling hepcidin gene expression is therefore an important goal. We identified a potential GATA binding site within the human hepcidin promoter. Indeed, in hepatic HepG2 cells, luciferase experiments demonstrated that mutation of this GATA binding site impaired the hepcidin promoter transcriptional activity in basal condition. Gel retardation experiment showed that GATA-4 could bind this site. Cotransfection of GATA-4 expression vector with an hepcidin promoter reporter construct enhanced hepcidin promoter transcriptional activity. Furthermore, modulation of GATA-4 mRNA expression using specific siRNAs downregulated endogenous hepcidin gene expression. Finally, we found that mutation of the GATA binding site impaired the interleukin6 induction of hepcidin gene expression, but did not prevent the bone morphogenetic protein6 response. In conclusion, our findings: i) indicate that GATA-4 may participate to the control of hepcidin expression, and ii) suggest that alteration of its expression could contribute to the development of iron-related disorders.
\end{abstract}

Key words: Hepcidin, GATA, gene expression, hepatocyte, iron metabolism, promoter. 


\section{INTRODUCTION}

Hepcidin is an iron regulated peptide synthesized mainly by hepatocytes in the liver, secreted in plasma [1-4], and involved in the regulation of iron metabolism [2] by controlling the expression of the cell iron exporter ferroportin [5]. Studies in mice, humans and cell cultures demonstrated that hepcidin mRNA levels were regulated by numerous factors including iron stores, inflammation, anemia, hypoxia, and transcription factors involved in hepatocyte differentiation [6]. Studies of patients with iron disorders, during hemochromatosis, including juvenile hemochromatosis [7] and adult forms of hemochromatosis as HFE-related hemochromatosis [8, 9], transferrin receptor 2 (TfR2)related hemochromatosis [10], and in chronic inflammatory diseases [11], demonstrated the involvement of hepcidin expression dysregulation.

Hepcidin expression is mainly upregulated by two pathways, the first one is the interleukin (IL)-6 pathway [12-14], which activates the signal transducer and activator of transcription 3 (STAT-3), whose binding site is located within the proximal $150 \mathrm{bp}$ from the start of translation. The second one is the bone morphogenetic protein (BMP) pathway, stimulated by BMP-6, $[15,16]$, which activates by phosphorylation the SMAD transcription factors. Two BMP-responsive elements (BMP-RE) $[17,18,19]$ are described, one (BMPRE1) is located near the STAT-3 binding site and the second (BMP-RE2) in the distal part of the hepcidin promoter. Other transcription factors have been reported to stimulate hepcidin gene expression, such as CCAAT/enhancer binding protein $\alpha(\mathrm{C} / \mathrm{EBP} \alpha)$ [20], hepatocyte nuclear factor $4 \alpha(H N F 4 \alpha)[19,20]$, upstream stimulatory factors 1 and 2 (USF1 and 2) [21], p53 [22], MRE-binding transcription factor-1 (MTF-1) [23], and cyclic AMP response element binding protein $\mathrm{H}$ (CREBH) [24].

GATA-1 transcription factor has been described to enhance murine TfR2 transcriptional activity, implying a potential role of GATA proteins in the regulation of genes involved in the control of iron metabolism [25]. Therefore, we performed an in silico analysis of hepcidin promoter that indicates the presence of a putative binding motif for members of the zinc finger GATA transcription factors. In the liver, GATA proteins have been previously reported to exert a role especially during hepatic development [26-28]. In the present study, we demonstrate that, in human HepG2 cells, GATA-4 could activate hepcidin gene expression by binding to its promoter 


\section{MATERIALS AND METHODS}

\section{Cell culture}

Human hepatoma HepG2 cells were grown in Minimum Essential Medium alpha (Invitrogen, France) supplemented with $10 \%$ fetal calf serum (Invitrogen, France), $100 \mathrm{Ul} / \mathrm{ml}$ penicillin, $100 \mu \mathrm{g} / \mathrm{ml}$ streptomycin and $2 \mathrm{mM} \mathrm{L-glutamine}$. Cells were maintained at $37^{\circ} \mathrm{C}$ under $5 \% \mathrm{CO}_{2}$.

\section{Plasmid constructions}

A fragment of $-2762 \mathrm{bp}$ from the translation start site of the human hepcidin promoter from the pGL3 basic vector (a kind gift of Martina Muckenthaler) was hydrolyzed and inserted into the pGL4.17 at the Kpn1-Xho1 restriction sites (Promega, France) among the firefly luciferase reporter gene to generate the $-2762 \mathrm{Hep} / \mathrm{Luc}$ plasmid construct. The internal mutations in BMP-RE, STAT-3 and GATA binding sites were made according to the Quick Change method (Stratagene, France) using the -2762 Hep/Luc as template and the internal primers described in Table 1. The identity of the constructs was confirmed by DNA sequencing.

\section{Transfection, luciferase assay}

Cells $\left(5 \times 10^{5}\right)$ were plated onto 12 -well plates. The day after $100 \mathrm{ng}$ of pGL4.17-hepcidin promoter was transfected into the cells together with the normalization plasmid renilla-SV40 (Promega, France). For cotransfection experiments, the human pcDNA.3.1.A-GATA-4 expression plasmid was added as indicated. In each experiment, a given construction was transfected in duplicate, and two different clones of each construction were tested in at least three distinct experiments. Plasmid transfections were performed using transfectin reagent (Bio-Rad, France) according to the manufacturer's instructions. After $48 \mathrm{~h}$, the cells were lysed and the luciferase activities were measured in cell lysates using the Dual-LuciferaseReporter assay system (Promega, France) and a Centro LB 960 luminometer (Berthold Technologies, France). For cell treatments either $50 \mathrm{ng} / \mathrm{ml}$ of human BMP-6 (R\&D systems, France) or $50 \mathrm{ng} / \mathrm{ml}$ of human IL-6 (R\&D systems, France) were added to the cells for $48 \mathrm{~h}$. Luciferase activity values represent firefly/renilla luciferase activity ratios relative to that obtained with the $-2762 \mathrm{Hep} /$ Luc construct, which was arbitrarily set at $100 \%$.

\section{Quantitative RT- PCR}

Two different specific siRNAs against GATA-4 (siRNA1 ref SI03246558; siRNA2 ref SIO3246894) and one control siRNA (ref 1022081), (Qiagen, France) were transfected in HepG2 cells as described above. Forty-eight hours later, total RNAs were extracted using

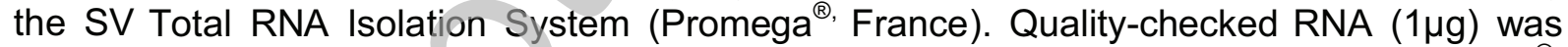
used for reverse transcription following the manufacturer's protocol (M-MLV-RT, Promega ${ }^{\circledR}$, France). We performed quantitative PCR in triplicate to evaluate the hepcidin, GATA-4 mRNA levels, using qPCRMasterMixPlus for $S Y B R^{\circledR}$ Greenl according to the manufacturer's instructions (Eurogentec ${ }^{\circledR}$, France). The qRT-PCR was run on ABI PRISM StepOne sequence detection system (Applied Bioscience, France). Each mRNA sample threshold cycle (Ct) value was normalized with Hprt (Hypoxanthine-Guanine Phosphoribosyl Transferase ) RNA Ct values. Primer sequences used for the mRNA amplification are described in Table 1.

\section{Electrophoretic Mobility Shift Assay.}

For gel retardation assays, HepG2 nuclear extract $(10 \mu \mathrm{g})$ were pre-incubated with $250 \mathrm{ng}$ of poly(dl-dC).poly(dl-dC), used as nonspecific competitor, in a binding buffer $(10 \mathrm{mM}$ Tris- $\mathrm{HCl}$ $\mathrm{pH} 7.5,50 \mathrm{mM} \mathrm{NaCl}, 1 \mathrm{mM}$ DTT, $1 \mathrm{mM}$ EDTA,5\% glycerol) for $10 \mathrm{~min}$ on ice. This mixture was then added to the binding buffer containing ${ }^{33} \mathrm{P}$-end-labeled probes described in Table 1 (100000 cpm/per well) either with or without specific competitor oligonucleotides containing wild type or mutated GATA site, in a final volume of $10 \mu \mathrm{l}$, and the incubation was carried out for a further $30 \mathrm{~min}$ at room temperature. Gel shift assays with purified polyclonal rabbit IgG anti-GATA-2, GATA-4 or GATA-6 (Santa Cruz, France) were performed under the same 
conditions except that the non-relevant antibody and pre-immune IgG were pre-incubated with the nuclear extracts for $1 \mathrm{~h}$ on ice. Complexes were resolved by electrophoresis on prerun Tris-Glycine $6 \%$ native polyacrylamide gels. After drying, the gels were autoradiographed overnight.

Statistical analysis.

Data represent means of at least three independent experiments (+/- SD). Statistical analyses were determined by using the Student's $t$ test. $p<0.05$ was considered as significant. 


\section{RESULTS AND DISCUSSION}

Mutations of the putative GATA binding site located near the BMP, IL-6 responsive elements down regulate the human hepcidin gene expression in basal condition.

The MatInspector algorithm (Genomatix, software $\mathrm{GmbH}$, http://.genomatix.de) was used to search for GATA binding motifs in the hepcidin promoter. GATA proteins, a family composed of 6 members (1 to 6 ) in vertebrates, contain a highly conserved DNA binding domain consisting of two zing finger motifs. A putative GATA binding site (A/T)GATA(A/G) [29] was located on the DNA minus strand, near the BMP-RE1 [17] and the STAT-3 binding site [12-14] (Figure 1A). To investigate the impact of this putative GATA binding site on hepcidin gene expression in basal condition, we performed transfection experiments in HepG2 cells using the wild type promoter inserted among the luciferase gene (-2762Hep/Luc construct), compared to a construct with mutations in the putative GATA binding site ($2762 \mathrm{Hep} /$ Luc GATA mutant). We observed a decrease of luciferase activity equivalent to that observed with mutations in the BMP or IL-6 responsive elements (Figure 1B), suggesting that this potential binding site plays a role in the control of hepcidin gene expression.

\section{GATA-4 binds to the human hepcidin promoter.}

We investigated GATA proteins expressed in HepG2 cells. Quantitative PCR experiments showed that GATA-4 was mainly expressed, GATA-2 and -6 in a lesser extent, whereas GATA-1, GATA-3 and GATA-5 were expressed at very low levels, if any (data not shown). Thus, to determine which GATA could bind to the hepcidin promoter, an EMSA (figure 2A) was performed using HepG2 nuclear extracts, a probe containing the GATA binding site and antibodies against either GATA-2,-4 or -6 . We observed the formation of three nucleoprotein complexes super-shifted using the anti-GATA-4 antibody whereas no super-shift was found with the anti-GATA-2 or anti-GATA-6 antibodies.

The specificity of formation of the nucleoprotein complexes containing GATA-4 was demonstrated by EMSA using a probe with the wild type GATA motif and unlabelled oligonucleotides containing wild-type or mutated GATA site in 25,50 or 100 fold molar excess. A competition for the binding of the nucleoprotein complexes was observed with the use of a cold competitor containing the wild-type GATA motif in excess, whereas a competitor containing the mutated GATA site had no effect (Figure 2B).

These results suggest that GATA-4 protein could specifically binds to the GATA binding site present within the human hepcidin promoter. GATA-4 plays a role in embryonic development. Thus, mice null for GATA-4 die between embryonic day 8 and 9 in part because of defects in heart morphogenesis. In addition, it has been reported that patients with GATA-4 haploinsufficiency due to an interstitial deletion of chromosome region 8p23.1 [30] or with mutations in GATA-4 gene [31] may present with congenital heart defect and physical anomalies. Beside a role of GATA-4 during embryogenesis, it is also expressed in the adult mouse in the heart, ovary, testis, lung, liver and small intestine and can regulate expression of genes [29]. Thus, in human hepatic cell lines, expressions of other hepatic genes, such as the cytochrome P450 2C9 gene in Huh-7 cells [32], and ABCG5/ABCG8 genes, that are implied in the hepatic excretion of cholesterol, in HepG2 cells [33], were reported to be significantly increased by GATA-4. In HepG2 cells GATA-4 and -6 were demonstrated to colocalize in the nuclei [33]. Therefore we investigated whether GATA-4 controls hepcidin gene expression.

\section{GATA-4 activates the human hepcidin gene expression.}

Thus, we evaluated the impact of GATA-4 transcription factor on hepcidin gene expression by cotransfection experiments combining the $-2762 \mathrm{Hep} / \mathrm{Luc}$ or $-2762 \mathrm{Hep} / \mathrm{Luc}$ GATA mutant constructs along with a human GATA-4 expression vector, which enhanced its expression by approximately 7 fold (Figure 3A). We observed an activation of hepcidin promoter transcriptional activity with the $-2762 \mathrm{Hep} / \mathrm{Luc}$ wild-type construct but not with the $2762 \mathrm{Hep} /$ Luc GATA mutant construct, suggesting that GATA-4 binds this DNA GATA motif and could activate hepcidin promoter transcriptional activity (Figure 3B). 
The impact of GATA-4 on endogenous hepcidin gene expression in HepG2 cells was investigated by experiments using siRNAs directed against GATA-4 (Figure 3C). We observed that a decrease of GATA-4 mRNA expression induced a significant decrease of hepcidin mRNA level (Figure 3D). This result confirmed a potential role of GATA-4 protein as activator of hepcidin mRNA expression.

\section{Mutations of the GATA binding site impair IL-6 response and prevent total responsiveness to BMP-6.}

We investigated the impact of mutations within the GATA binding site on BMP-6 or IL6 hepcidin gene induction. Thus, we transfected the $-2762 \mathrm{Hep} / \mathrm{Luc}$ or $-2762 \mathrm{Hep} / \mathrm{Luc}$ GATA mutant constructs and exposed cells to $50 \mathrm{ng} / \mathrm{ml}$ of BMP-6 or IL-6. In the presence of BMP-6, as expected, the $-1024 \mathrm{Hep} / \mathrm{Luc}$ construct that contains only one BMP-RE was less inducible than the $-2762 \mathrm{Hep} / \mathrm{Luc}$ construct, which contains the two BMP responsive elements [18, 33]. BMP-6 induced the $-2762 \mathrm{Hep} /$ Luc GATA mutant transcriptional activity. Therefore, the impairment of GATA binding did not prevent a response to this cytokine, but we did not observe total hepcidin promoter transcriptional activity as obtained with the wild-type promoter (Figure 4). When cells were exposed to IL-6, we did not observe an induction of the -2762Hep/Luc GATA mutant transcriptional activity (Figure 4). Thus, the hepcidin promoter IL-6 response was markedly impaired by the absence of GATA binding. It has been reported previously that mutation of the BMP-RE1 also severely impaired hepcidin activation in response to IL-6 [17, 34]. It might be due to the fact that IL-6 signaling requires the presence of associated transcription factors to STAT-3 phosphorylated protein in order to recruit and/or stabilize co-factors that bring RNA polymerase II complex. Therefore, GATA-4 could be one of these transcriptional factors, and the observation of three nucleoprotein complexes in EMSA experiment could be related to interactions between GATA-4 and co-factors. For BMP/SMAD pathway, despite GATA binding site mutations, we observed a response to BMP-6 treatment suggesting that activated SMAD proteins could bring the co-factors required to hepcidin gene activation.

In conclusion, our findings indicate that GATA-4 transcription factor may participate to the control of hepcidin expression. Therefore, patho-physiological situations which could impact the expression of GATA-4 could also, in turn, modulate hepcidin expression and contribute to iron metabolism alterations.

\section{AUTHOR CONTRIBUTION}

Marie-Laure Island designed and performed experiments, analyzed data and wrote the manuscript. Patricia Leroyer and Nadia Fatih performed experiments. Pierre Brissot and Olivier Loréal initiated the study, analyzed data and wrote the paper.

\section{FUNDING}

This study was supported by the EEC FP6 program Euroiron1 [grant number:LSHM-CT2006-037296] and the ANR IRONREG. [grant number:ANR-09-GENO-016-02]. 


\section{REFERENCES}

1 Krause, A., Neitz, S., Magert, H. J., Schulz, A., Forssmann, W. G., Schulz-Knappe, P. and Adermann, K. (2000) LEAP-1, a novel highly disulfide-bonded human peptide, exhibits antimicrobial activity. FEBS Lett. 480, 147-150

2 Nicolas, G., Bennoun, M., Devaux, I., Beaumont, C., Grandchamp, B., Kahn, A. and Vaulont, S. (2001) Lack of hepcidin gene expression and severe tissue iron overload in upstream stimulatory factor 2 (USF2) knockout mice. Proc. Natl. Acad. Sci. U.S.A. 98, 87808785

3 Park, C. H., Valore, E. V., Waring, A. J. and Ganz, T. (2001) Hepcidin, a urinary antimicrobial peptide synthesized in the liver. J. Biol. Chem. 276, 7806-7810

4 Pigeon, C., Ilyin, G., Courselaud, B., Leroyer, P., Turlin, B., Brissot, P. and Loreal, O. (2001) A new mouse liver-specific gene, encoding a protein homologous to human antimicrobial peptide hepcidin, is overexpressed during iron overload. J. Biol. Chem. 276, $7811-7819$

5 Nemeth, E., Tuttle, M. S., Powelson, J., Vaughn, M. B., Donovan, A., Ward, D. M., Ganz, T. and Kaplan, J. (2004) Hepcidin regulates cellular iron efflux by binding to ferroportin and inducing its internalization. Science 306, 2090-2093

6 Hentze, M. W., Muckenthaler, M. U., Galy, B. and Camaschella, C. Two to tango: regulation of Mammalian iron metabolism. Cell 142, 24-38

7 Roetto, A. and Camaschella, C. (2005) New insights into iron homeostasis through the study of non-HFE hereditary haemochromatosis. Best Pract. Res. Clin. Haematol. 18, 235-250

8 Bridle, K. R., Frazer, D. M., Wilkins, S J., Dixon, J.L., Purdie, D. M., Crawford, D. H., Subramaniam, V. N., Powell, L. W., Anderson, G. J. and Ramm, G. A. (2003) Disrupted hepcidin regulation in HFE-associated haemochromatosis and the liver as a regulator of body iron homoeostasis. Lancet 361, 669-673

9 Gehrke, S. G., Kulaksiz, H., Herrmann, T., Riedel, H. D., Bents, K., Veltkamp, C. and Stremmel, W. (2003) Expression of hepcidin in hereditary hemochromatosis: evidence for a regulation in response to the serum transferrin saturation and to non-transferrin-bound iron. Blood 102, 371-376

10 Pelucchi, S., Mariani, R., Trombini, P., Coletti, S., Pozzi, M., Paolini, V., Barisani, D. and Piperno, A. (2009) Expression of hepcidin and other iron-related genes in type 3 hemochromatosis due to a novel mutation in transferrin receptor-2. Haematologica 94, 276279

11 Nemeth, E., Valore, E. V., Territo, M., Schiller, G., Lichtenstein, A. and Ganz, T. (2003) Hepcidin, a putative mediator of anemia of inflammation, is a type II acute-phase protein. Blood 101, 2461-2463

12 Pietrangelo, A., Dierssen, U., Valli, L., Garuti, C., Rump, A., Corradini, E., Ernst, M., Klein, C. and Trautwein, C. (2007) STAT3 is required for IL-6-gp130-dependent activation of hepcidin in vivo. Gastroenterology 132, 294-300

13 Verga Falzacappa, M. V., Vujic Spasic, M., Kessler, R., Stolte, J., Hentze, M. W. and Muckenthaler, M. U. (2007) STAT3 mediates hepatic hepcidin expression and its inflammatory stimulation. Blood 109, 353-358

14 Wrighting, D. M. and Andrews, N. C. (2006) Interleukin-6 induces hepcidin expression through STAT3. Blood 108, 3204-3209

15 Andriopoulos, B., Jr., Corradini, E., Xia, Y., Faasse, S. A., Chen, S., Grgurevic, L., Knutson, M. D., Pietrangelo, A., Vukicevic, S., Lin, H. Y. and Babitt, J. L. (2009) BMP6 is a key endogenous regulator of hepcidin expression and iron metabolism. Nat.Genet. 41, 482487

16 Meynard, D., Kautz, L., Darnaud, V., Canonne-Hergaux, F., Coppin, H. and Roth, M. P. (2009) Lack of the bone morphogenetic protein BMP6 induces massive iron overload. Nat. Genet. 41, 478-481 
17 Verga Falzacappa, M. V., Casanovas, G., Hentze, M. W. and Muckenthaler, M. U. (2008) A bone morphogenetic protein (BMP)-responsive element in the hepcidin promoter controls HFE2-mediated hepatic hepcidin expression and its response to IL-6 in cultured cells. J. Mol. Med. 86, 531-540

18 Casanovas, G., Mleczko-Sanecka, K., Altamura, S., Hentze, M. W. and Muckenthaler, M. U. (2009) Bone morphogenetic protein (BMP)-responsive elements located in the proximal and distal hepcidin promoter are critical for its response to HJV/BMP/SMAD. J. Mol. Med. 87, 471-480

19 Truksa, J., Lee, P. and Beutler, E. (2009) Two BMP responsive elements, STAT, and bZIP/HNF4/COUP motifs of the hepcidin promoter are critical for BMP, SMAD1, and HJV responsiveness. Blood 113, 688-695

20 Courselaud, B., Pigeon, C., Inoue, Y., Inoue, J., Gonzalez, F. J., Leroyer, P., Gilot, D., Boudjema, K., Guguen-Guillouzo, C., Brissot, P., Loreal, O. and Ilyin, G. (2002) C/EBPalpha regulates hepatic transcription of hepcidin, an antimicrobial peptide and regulator of iron metabolism. Cross-talk between C/EBP pathway and iron metabolism. J. Biol. Chem. 277, 41163-41170

21 Bayele, H. K., McArdle, H. and Srai, S. K. (2006) Cis and trans regulation of hepcidin expression by upstream stimulatory factor. Blood 108, 4237-4245

22 Weizer-Stern, O., Adamsky, K., Margalit, O., Ashur-Fabian, O., Givol, D., Amariglio, N. and Rechavi, G. (2007) Hepcidin, a key regulator of iron metabolism, is transcriptionally activated by p53. Br. J. Haematol. 138, 253-262

23 Balesaria, S., Ramesh, B., McArdle, H., Bayele, H. K. and Srai, S. K. Divalent metaldependent regulation of hepcidin expression by MTF-1. FEBS Lett. 584, 719-725

24 Vecchi, C., Montosi, G., Zhang, K., Lamberti, I., Duncan, S. A., Kaufman, R. J. and Pietrangelo, A. (2009) ER stress controls iron metabolism through induction of hepcidin. Science 325, 877-880

25 Kawabata, H., Germain, R. S., Ikezoe, T., Tong, X., Green, E. M., Gombart, A. F. and Koeffler, H. P. (2001) Regulation of expression of murine transferrin receptor 2. Blood 98, 1949-1954

26 Haworth, K. E., Kotecha, S., Mohun, T. J. and Latinkic, B. V. (2008) GATA4 and GATA5 are essential for heart and liver development in Xenopus embryos. BMC Dev. Biol. 8, 74

27 Zaret, K. S. (2001) Hepatocyte differentiation: from the endoderm and beyond. Curr. Opin. Genet. Dev. 11, 568-574

28 Zhao, R. and Duncan, S. A. (2005) Embryonic development of the liver. Hepatology 41, 956-967

29 Molkentin, J. D. (2000) The zinc finger-containing transcription factors GATA-4, -5, and -6 . Ubiquitously expressed regulators of tissue-specific gene expression. J. Biol. Chem. 275, 38949-38952

30 Pehlivan, T., Pober, B. R., Brueckner, M., Garrett, S., Slaugh, R., Van Rheeden, R., Wilson, D. B., Watson, M. S. and Hing, A. V. (1999) GATA4 haploinsufficiency in patients with interstitial deletion of chromosome region 8p23.1 and congenital heart disease. Am. J. Med. Genet. 83, 201-206

31 Tomita-Mitchell, A., Maslen, C. L., Morris, C. D., Garg, V. and Goldmuntz, E. (2007) GATA4 sequence variants in patients with congenital heart disease. J. Med. Genet. 44, 779783

32 Mwinyi, J., Nekvindova, J., Cavaco, I., Hofmann, Y., Pedersen, R. S., Landman, E., Mkrtchian, S. and Ingelman-Sundberg, M. New insights into the regulation of CYP2C9 gene expression. the role of the transcription factor GATA-4. Drug Metab. Dispos. 38, 415-421

33 Sumi, K., Tanaka, T., Uchida, A., Magoori, K., Urashima, Y., Ohashi, R., Ohguchi, H., Okamura, M., Kudo, H., Daigo, K., Maejima, T., Kojima, N., Sakakibara, I., Jiang, S., Hasegawa, G., Kim, I., Osborne, T. F., Naito, M., Gonzalez, F. J., Hamakubo, T., Kodama, T. and Sakai, J. (2007) Cooperative interaction between hepatocyte nuclear factor 4 alpha and GATA transcription factors regulates ATP-binding cassette sterol transporters ABCG5 and ABCG8. Mol. Cell. Biol. 27, 4248-4260 
34 Island, M. L., Jouanolle, A. M., Mosser, A., Deugnier, Y., David, V., Brissot, P. and Loreal, O. (2009) A new mutation in the hepcidin promoter impairs its BMP response and contributes to a severe phenotype in HFE related hemochromatosis. Haematologica 94, 720724 


\section{FIGURE LEGENDS}

Figure 1 : Mutations of the putative GATA binding site located near the BMP, IL-6 responsive elements down regulate the human hepcidin gene expression in basal condition.

A) Nucleotide sequence of the human hepcidin promoter and putative GATA binding site location. The TATA sequence and the translational start site are underlined. The GATA, STAT-3 binding sites and the BMP-RE are underlined and enclosed by grey boxes.

B) Effect of mutations within the GATA binding site on hepcidin promoter transcriptional activity under basal condition. HepG2 cells were transfected with Hep/Luc constructs as indicated in the figure for $48 \mathrm{~h}$. Luciferase activity values represent Firefly/Renilla Luciferase activities ratios relative to the ratio obtained with the -2762 Hep/Luc plasmid construct, which was arbitrarily set at $100 \% .{ }^{* * *} \mathrm{P}<0.001$.

Figure 2 : GATA-4 binds to the human hepcidin promoter.

(A) To investigate the GATA factors that could bind to the putative GATA binding site we performed EMSA, using HepG2 nuclear extracts incubated with radiolabeled probes containing the wild-type GATA motif and either a non-relevant antibody or antibodies against GATA-2, -4 or -6 .

(B) Binding specificity of GATA-4 complexes was ascertained by EMSA using HepG2 nuclear extracts incubated with radiolabeled probes containing the mutated GATA site or the wild-type GATA motif and 25, 50, 100 fold excess of cold competitor oligonucleotides containing the wild-type or mutated GATA binding site.

Figure 3: GATA-4 activates the human hepcidin gene expression.

A) Effect of GATA-4 on hepcidin promoter transcriptional activity was determined by transfection experiments with the $-2762 \mathrm{Hep} / \mathrm{Luc}$ or $-2762 \mathrm{Hep} / \mathrm{Luc}$ GATA mutant along with a GATA-4 expression plasmid. GATA-4 mRNA expression was enhanced by approximately 7 fold in this experiment. Results are expressed in percentage compared to the value obtained with the control well transfected with the $-2762 \mathrm{Hep} / \mathrm{Luc}$ and the empty vector set at $100 \%$. In B) Luciferase activity values represent Firefly/Renilla Luciferase activities ratios relative to the ratio obtained with the $-2762 \mathrm{Hep} / \mathrm{Luc}$ plasmid construct, which was arbitrarily set at $100 \%$.

Effect of two specific siRNAs directed against GATA-4 (C) transfected in HepG2 cells on hepcidin mRNA expression (D). Results are expressed in percentage compared to the value obtained with the control well transfected with a control siRNA set at $100 \%$.

${ }^{*} \mathrm{P}<0.05,{ }^{* * *} \mathrm{P}<0.001$, ns : non significant.

Figure 4 : Mutations of the GATA binding site impair the IL-6 response and prevent the total responsiveness to BMP-6.

HepG2 cells were transfected with Hep/Luc constructs as indicated in the figure and treated or not with $50 \mathrm{ng} / \mathrm{ml}$ of BMP-6 or IL-6 cytokines for $48 \mathrm{~h}$. Luciferase activity values represent Firefly/Renilla Luciferase activities ratios relative to the ratio obtained with the $-2762 \mathrm{Hep} / \mathrm{Luc}$ plasmid construct, which was arbitrarily set at $100 \%$. ${ }^{* *} \mathrm{P}<0.001$, ns : non significant. 
Biochemical Journal Immediate Publication. Published on 24 May 2011 as manuscript BJ20110225

\begin{tabular}{|c|c|}
\hline \multicolumn{2}{|c|}{ Primers used in Quick Change experiments (mutations are underlined) } \\
\hline BMP-RE1 mutant F & cccgccttttcggtgccaccaccttcttgg \\
\hline BMP-RE1 mutant R & ccaagaaggtggtggcáccgaaaaggcggg \\
\hline BMP-RE2 mutant F & ccttgcaccaaggctctggtgcetgtgetgtgaccc \\
\hline BMP-RE2 mutant R & gggtcacagcacaggcaccagagccttggtgcaagg \\
\hline STAT3 mutant $F$ & cgccaccaccttcttggccgtgagacagagcaaaggg \\
\hline STAT3 mutant $R$ & ccctttgctctgtctcacggccaagaaggtggtggcg \\
\hline GATA mutant $F$ & cctgtcgctctgttcccgcttaagtctcccgccttttcggcgcc \\
\hline GATA mutant $R$ & ggcgccgaaaaggcgggagacttaagcgggaacagagcgacagg \\
\hline \multicolumn{2}{|c|}{ Primers used in qPCR } \\
\hline GATA-4 F & agaaaacggaagcccaagaac \\
\hline GATA-4 R & ctggagttgctggaagcac \\
\hline Hepcidin F & cacttccccatctgcattttc \\
\hline Hepcidin R & gtcttgcagcacatcccaca \\
\hline HPRT F & gctttccttggtcaggcagta \\
\hline HPRT R & aagcttgcgaccttgaccat \\
\hline \multicolumn{2}{|c|}{ Primers used in EMSA (mutations are underlined) } \\
\hline GATA wild type $F$ & tgttcccgcttatctctcccgcet \\
\hline GATA wild type $R$ & aggcgggagagataagcgggaaca \\
\hline GATA mutant $F$ & tgttcccgcttaagtctcccgcct \\
\hline GATA mutant $R$ & aggcgggagacttaagcgggaaca \\
\hline
\end{tabular}

Table 1. Sequences of primers used in the study. 
B) Biochemical Journal Immediate Publication. Published on 24 May 2011 as manuscript BJ20110225

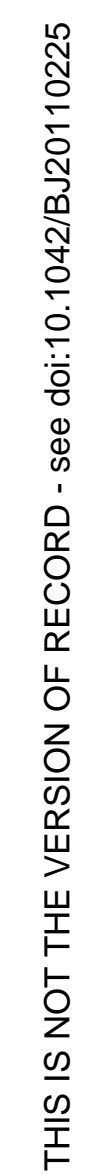

A

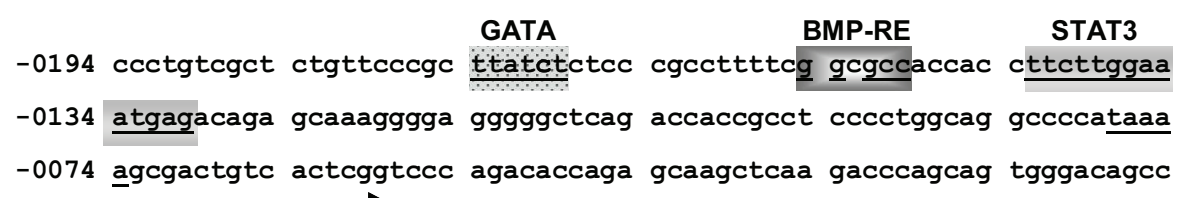
-0014 agacagacgg cacghtggca ctgagctccc agatctgggc cgcttgcctc ctgctcctcc

B

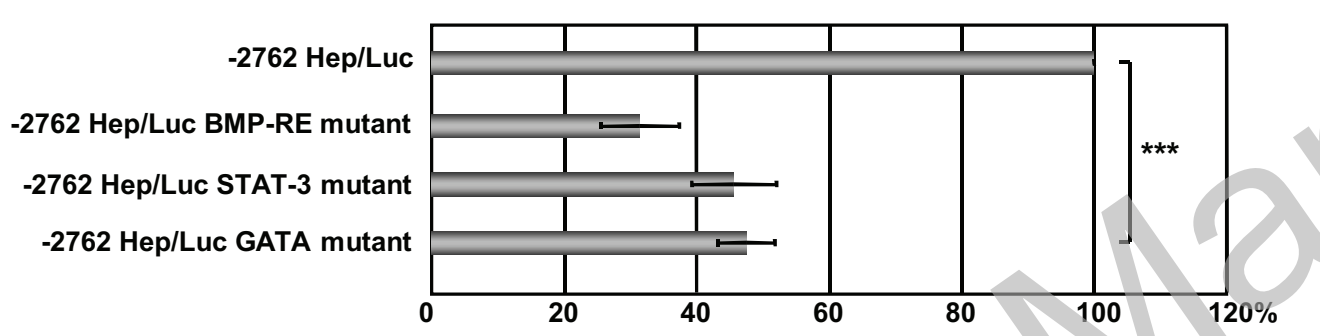

FIGURE 1 
B) Biochemical Journal Immediate Publication. Published on 24 May 2011 as manuscript BJ20110225

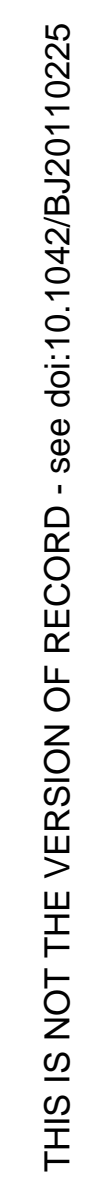

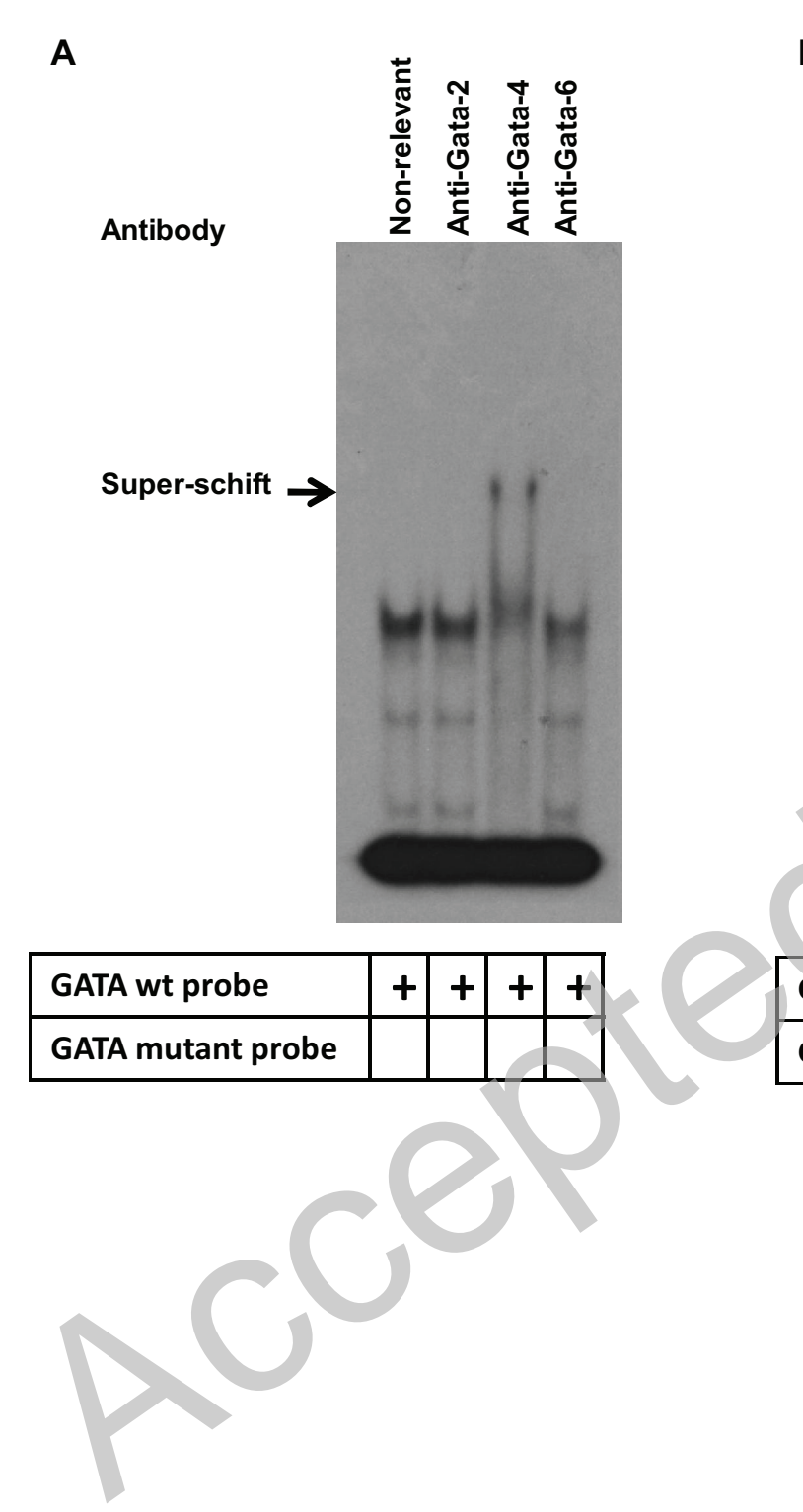

B

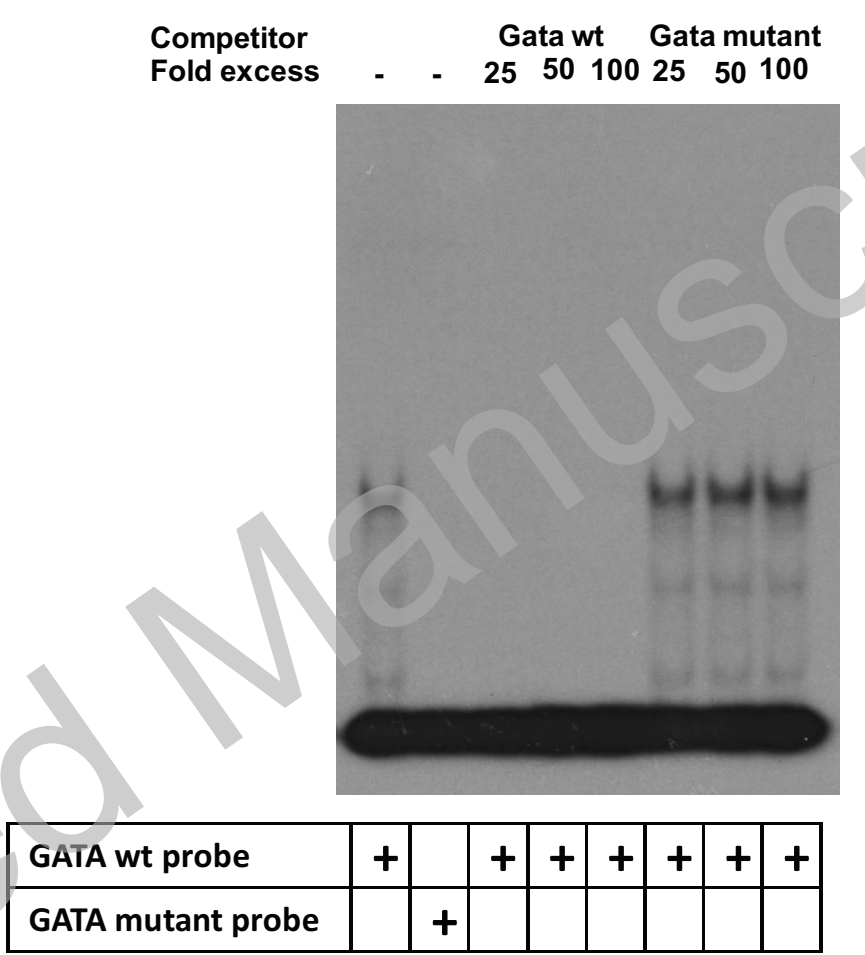

\section{FIGURE 2}


B Biochemical Journal Immediate Publication. Published on 24 May 2011 as manuscript BJ20110225

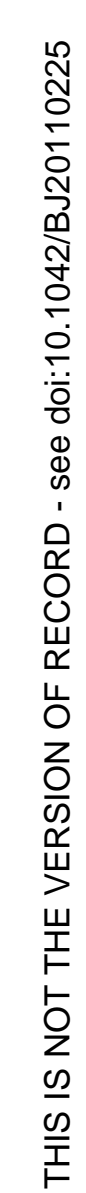

A

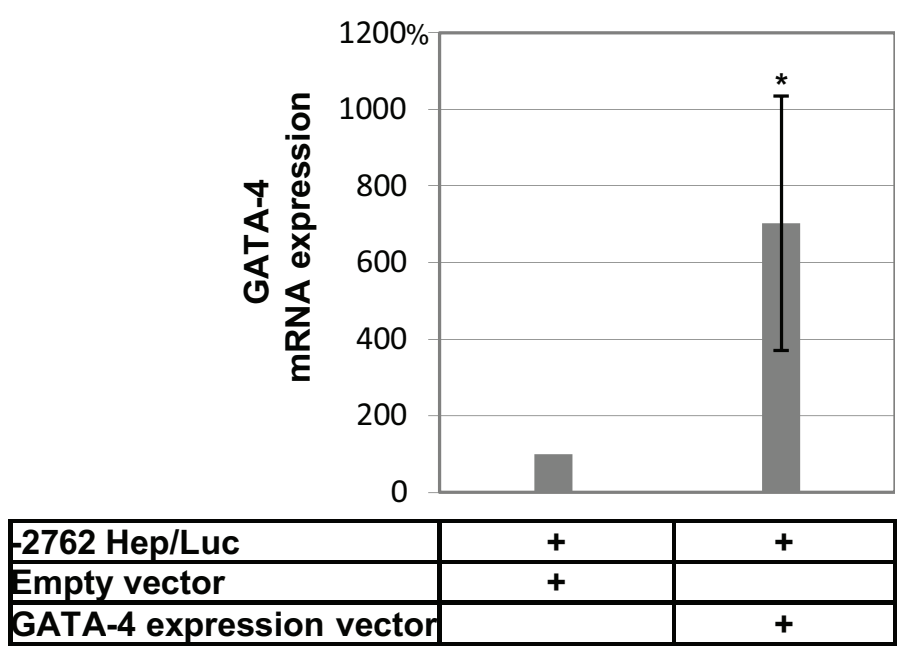

C

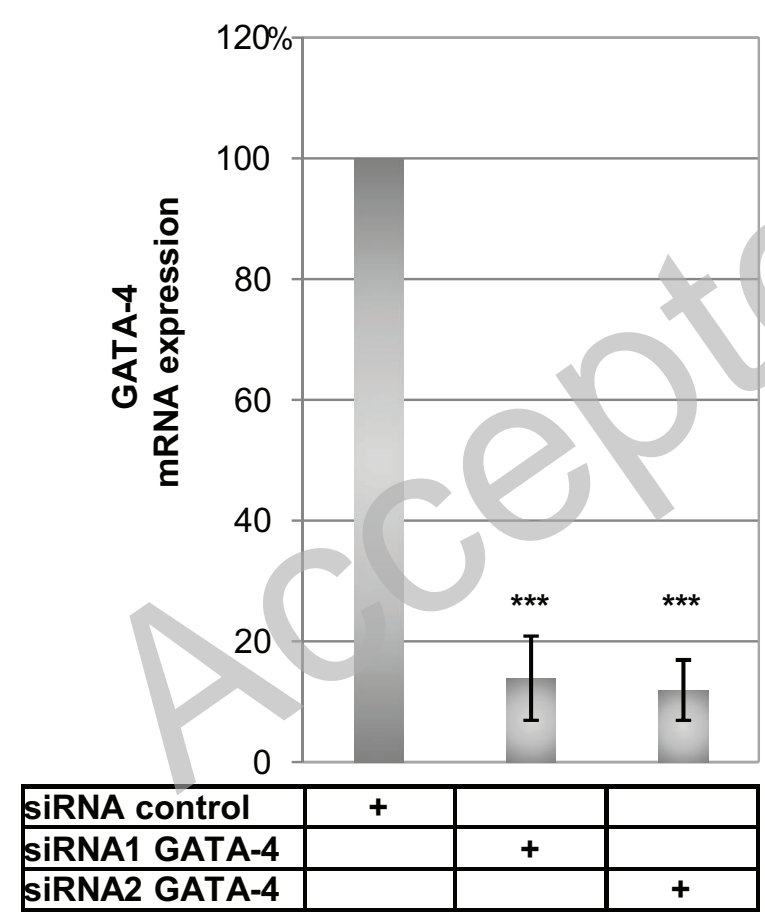

B

125 ng GATA-4

Expression

plasmid

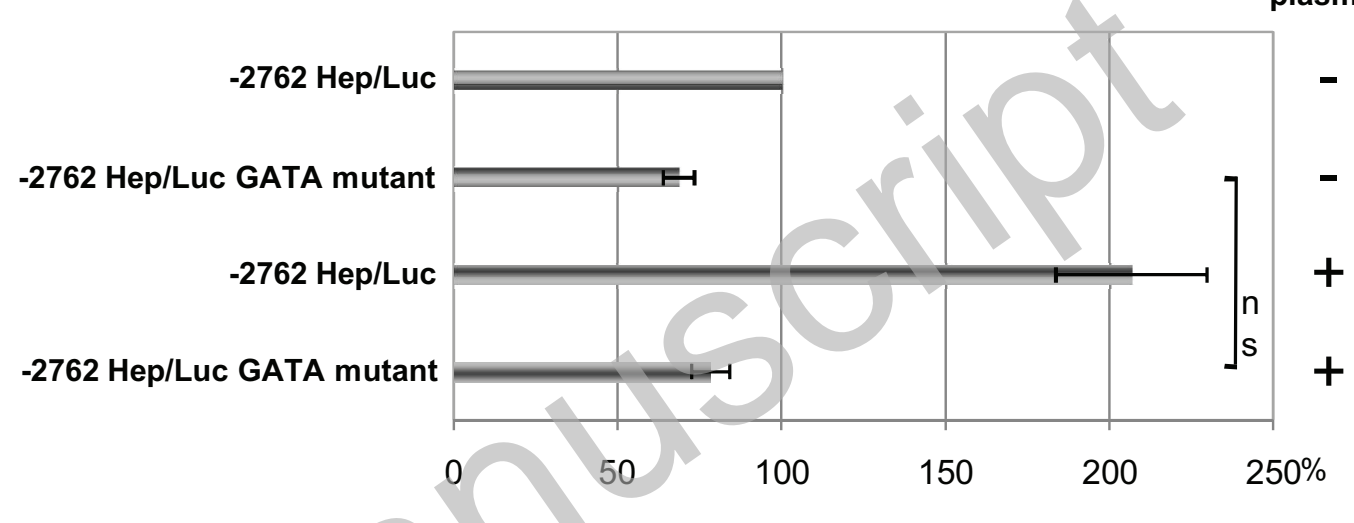

D

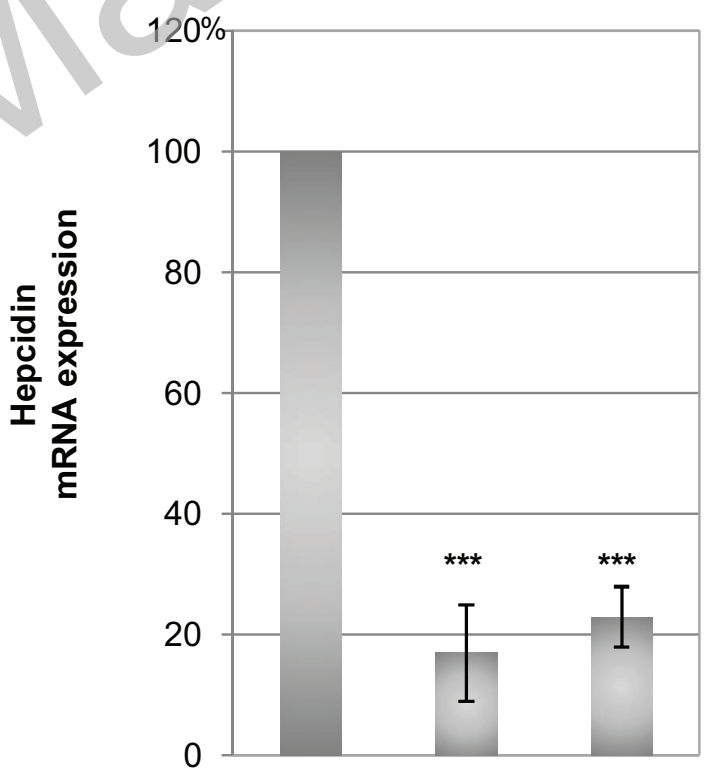

FIGURE 3

Licenced copy. Copying is not permitted, except with prior permission and as allowed by law.

(C) 2011 The Authors Journal compilation (C) 2011 Portland Press Limited

\begin{tabular}{|l|l|l|l|}
\hline siRNA control & + & & \\
\hline SiRNA1 GATA-4 & & + & \\
\hline siRNA2 GATA-4 & & & + \\
\hline
\end{tabular}




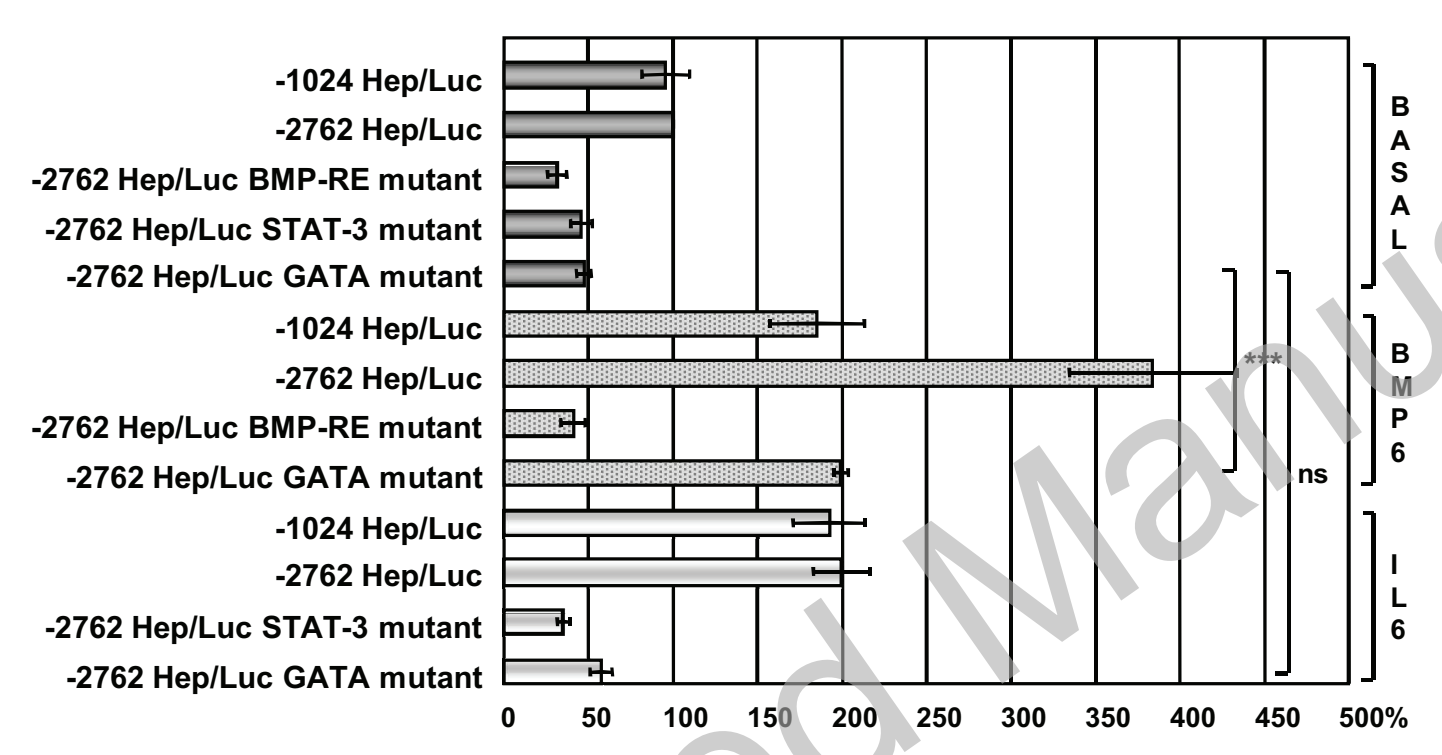

\section{FIGURE 4}

